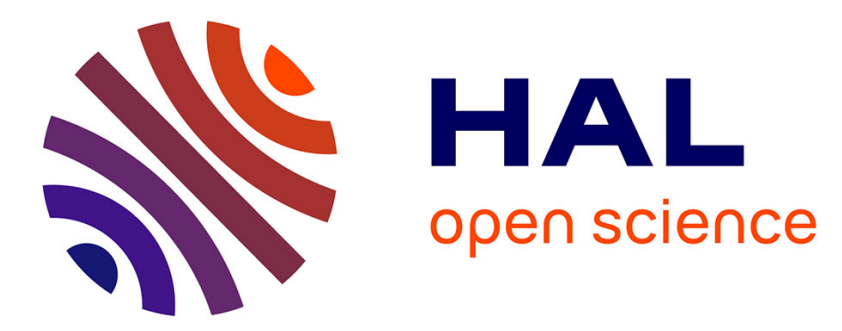

\title{
Intimate Encounters with the State in Post-War Luanda, Angola \\ Chloé Buire
}

\section{To cite this version:}

Chloé Buire. Intimate Encounters with the State in Post-War Luanda, Angola. The Journal of Development Studies, 2018, 54 (12), pp.2210-2226. 10.1080/00220388.2018.1460467 . hal-01790464

\section{HAL Id: hal-01790464 https://hal.science/hal-01790464}

Submitted on 15 Jul 2019

HAL is a multi-disciplinary open access archive for the deposit and dissemination of scientific research documents, whether they are published or not. The documents may come from teaching and research institutions in France or abroad, or from public or private research centers.
L'archive ouverte pluridisciplinaire HAL, est destinée au dépôt et à la diffusion de documents scientifiques de niveau recherche, publiés ou non, émanant des établissements d'enseignement et de recherche français ou étrangers, des laboratoires publics ou privés. 


\title{
Intimate Encounters \\ with the State in Post-War Luanda, Angola
}

\section{Chloé Buire}

Les Afriques dans le Monde, CNRS, Pessac, France

\begin{abstract}
Since the end of the war in 2002, Luanda has become an iconic site of urban transformation in the context of a particularly entrenched oligarchic regime. In practice however, urban dwellers are often confronted with a 'deregulated system' that fails to advance a coherent developmental agenda. The paper narrates the trajectory of a family forcibly removed from the old city to the periphery. It shows how citydwellers experience the control of the party-state through a series of encounters with authority across the city. Questioning the intentionality of a state that appears at the same time omnipotent and elusive, openly violent and subtly hegemonic, the paper reveals the fine mechanisms through which consent is fabricated in the intimacy of the family.
\end{abstract}

In 2001, guerrilla leader Jonas Savimbi is hiding in the hinterlands of Angola; but on the Atlantic coast, the shadows of the civil war are dissipating and the Popular Movement for the Liberation of Angola (MPLA), the ruling party of Angola since 1975, announces ambitious reconstruction works in the capital city Luanda. In an old bairro (neighbourhood) near the city centre, Avo Monteiro, once a cook at one of the best hotels in town, gets the notice that will change the life of his whole family: his house is to be demolished to give way to a new road. A few months later, Savimbi is killed; the peace treaty that unfolds allows the MPLA to extend its control to the entire country and consolidate its grasp on all levels of government. As compensation for his eviction, Avo Monteiro receives a small twobedroom house located $25 \mathrm{~km}$ away from the centre, in a newly built neighbourhood called Panguila. The roof is made of corrugated iron sheets, the walls are nude cement blocks and the unfenced plot opens up to a dirt road. Avo passes away a few months before his home is destroyed. For the Monteiros, it is the end of an era. They are now urban outcasts, victims of the raw power of an authoritarian state. Fifteen years later, the story has turned around. Nine of Avo's children and grandchildren have moved to Panguila. What started as an isolated relocation site now counts over 80,000 inhabitants. Panguila has become one of many new suburban neighbourhoods within a city that grew from 5.8 to 6.9 million in a decade and the Monteiros act as brokers on its flourishing - yet informal - real estate market. The mushrooming peripheries of Luanda feed a new political discourse promising social housing to the 
masses and contribute to the reinforcement of the MPLA. Receiving 71 per cent of the votes during the general elections of 2012, the party that used to rule the People's Republic of Angola (1975-1992) seems to have succeeded in its transition to multipartism without losing its hegemonic power (Péclard, 2008; Schubert, 2010; Soares de Oliveira, 2015).

Between the grand narrative of national reconstruction and developmentalism advertised by the ruling party, and the multifaceted experience of a deregulated urban system marked by authoritarianism, this paper digs into 'the multiple sites in which state processes and practices are recognizable through their effects' (Trouillot, 2001, p. 126). It looks beyond the apparent unsustainability of a neopatrimonial petro-state, to ask how political hegemony is concretely produced on the ground.

If the reinforcement of the oligarchy through the economic opportunities that arose at the end of the civil war prompted a series of works on the tactics of the elite to entrench its privilege, little has been published about what it means to ordinary urban dwellers to be confronted everyday with a ruler that appears at the same time powerful yet unable to control urban growth.

The paper starts with a discussion of Angola's 'authoritarian conversion' in the new millennium. It explores Ananya Roy's hypothesis of urban informality as the product of intentional deregula $\neg$ tion, or to quote her directly, of a 'calculated informality, one that involves purposive action and planning, and one where the seeming withdrawal of regulatory power creates a logic of resource allocation, accumulation, and authority' (Roy, 2009a, p. 83). The tension between 'purposive action' on the one hand, and 'withdrawal of power' on the other hand, is at the core of the urban experience in Luanda. A brutal eviction suggests that central authorities indeed have the power to deliberately maintain citydwellers in the margins of the law, but the reality of peri-urban development in Luanda obscures these mechanisms of 'calculated informality'. The paper con $\neg$ tends that an intimate narrative grounded in the life of a family in Luanda helps to tie together the two facets of this hegemonic system, between the dynamics of domination from above, and the diffused production of consent rooted in daily life. To this end, the paper turns to the story of the Monteiro family. ${ }^{1}$ From their eviction from the city in 2002 to their new life in the northern periphery of Luanda nowadays, the Monteiro's urban trajectory reveals key moments of encounters in which the conundrums of legitimised abuse are felt and enacted. The first encounter takes the form of a forced removal that expresses a direct confrontation with the omnipotence of an authoritarian ruler. The double process of destruction (eviction) and provision (relocation) is disconcerting. Dehumanising and benevolent at the same time, the state appears

\footnotetext{
${ }^{1}$ This research was conducted in Luanda between March 2012 and August 2013. As I explain below, all names have been changed and any details that could give away the identity of my respondents were omitted.
} 
unpredictable and potentially arbitrary, breaking away from the classical reciprocity of patronagebased forms of authority.

The second encounter stands in sharp contrast with this idea of a strong, unchallenged state. In Panguila, the residents' own investments in their new home are what ultimately transformed the relocation site into a fully urbanised neighbourhood, not the government's plans (Buire, 2014; Croese, 2013). This organic consolidation hollows out the space theoretically ascribed to the state. 'Twilight institutions' (Lund, 2006) emerge to respond to aspirations for social ordering. The slow, bottom-up urbanisation of Panguila shows that public authority is also channelled through informal platforms that partly escape the formal mechanisms of state power. However, the ruling party largely influences twilight institutions. The second encounter finally confirms Roy's hypothesis on the existence of grey areas where the party-state seems to withdraw from daily life but nonetheless continues to drive the logic of public authority.

The third encounter looks further into the family unit. After Avo's death, his oldest stepson took the place of 'the Big Man', reproducing within the family the same kind of personification of power that is classically described as a trait of authoritarianism. This last encounter eventually derails the question of intentionality. Suggesting that top-down authority is maintained and normalised through kinship and family solidarity, it invites us to reflect on how overt dissent is being shut down at the most intimate scale of social life.

Finally, I argue that rather than a vertical confrontation with a dominant party-state where 'the top' unquestioningly intends to subjugate 'the bottom', hegemonic power can be described as an accumulation of 'ambiguities' (Roy, 2009a, p. 84) that are experienced in the most mundane and intimate experiences of urban dwellers.

\section{Beyond developmental miracle and neopatrimonial nightmare: reading post-war Angolan state through its daily effects}

Since the end of the civil war in 2002, Angola has attracted two main discourses. On the one hand, many observers emphasise the 'miraculous growth' of the country, and celebrate the opening of a new frontier for global capitalism (Financial Times, 2007; Insurance Times, 2012). On the other hand, political analysts diagnose a situation of 'failed state' marked by neopatrimonialism and on the verge of social explosion (Hodges, 2004; Malaquias, 2007; Sogge, 2009). Angolan specialist Ricardo Soares de Oliveira (2007) speaks of a 'successful failed state' to describe how a narrow web of business interests controlled by the elite flourishes while running parallel to derelict state institutions that 
'barely work and are unable to fulfil their function' (p. 614). Inspired by the work of Bayart (2006) and Chabal and Daloz (1999), literature on Angola provides detailed accounts of the strategies used by the oligarchy to maintain the status quo (see for example Roque [2011] on the workings of a 'shadow government' and Corkin [2013] on the manipulation of Chinese loans by Angolan elites). In his recent book, Soares de Oliveira (2015) pieces together testimonies of high level politicians, CEOs and investors to describe the concentration of power in the hands of a restricted elite surrounding the President. In this paper, I intend to complement these perspectives that focus on the ruling class by exploring how the 'successful failure' of the state is perceived and experienced by ordinary citizens in Luanda. $^{2}$

\subsection{The hegemonic conversion of post-socialist Angola}

In 2004, only two years after the signature of the peace treaty, Christine Messiant vehemently rejected the analyses that saw Angola as a 'young' or 'emerging' democracy. For her, the 'systemic corruption' that pervaded all state institutions, the strict control of the economy and the generalised 'cooptationneutralisa $\neg$ tion' of any dissent (outside or within the MPLA) were clear signs that, 'what has happened in Angola is in effect the conversion of the political system from a single-party dictatorial structure to an authoritarian hegemonic dispensation adapted to multiparty electoral politics' (Messiant, 2008, p. 356). In the last decade, new research corroborated the hypothesis of a hegemonic 'adaptation' of the MPLA (Péclard, 2008).

Political anthropology provides detailed accounts of how the abstract idea of the state is constantly (re)embedded and (re-)defined in the daily experience of ordinary citizens, or, to quote Navaro-Yashin (2002) in 'public life', as intangible as it can be (see also Das \& Poole, 2004; Fuller \& Bénéï, 2001; Hagmann \& Péclard, 2010; Trouillot, 2001). This critical field has been fertile in Angolan political studies since the end of the war. Recent works look at the monitoring of associational life (Amundsen \& Abreu, 2006; Gastrow, 2013), offer critical descriptions of living conditions, especially in Luanda (Seibert, 2007; Tomâs, 2012; Croese, 2013) and reflect more broadly on the meaning of 'peace building' in the absence of formal reconciliation programmes (Malaquias, 2007; Pearce, 2005). Jon

\footnotetext{
${ }^{2}$ Despite new academic research conducted in Angola nowadays, most groundwork is done by journalists and activists based in Luanda. Valuable insights into current socio-political dynamics come from reports done by local NGOs such as Development Workshop (2005), international watchdogs such as Amnesty International (2003) and Human Rights Watch (2007), or anonymously circulated online. This material cannot always be used as consistent data, but it greatly influences the present work. Another source of inspiration comes from fiction work by authors such as Pepetela (2012), José Eduardo Agualusa (2009), or Ondjaki (2012).
} 
Schubert (2017) provides a particularly convincing analysis of 'the coproduction of hegemony' (p. 2), 'arguing that even explicitly oppositional political action has to tap into the repertoires of dominant ideology to be effective' (p. 159). Schubert not only deconstructs official narratives of independence and 'Angolanness' (angolanidade), he also looks at the practices and symbolisms of kinship and money-making to show the inextricable links between the elite and the people that characterise what is colloquially referred to as 'the system' (o sistema) (Schubert, 2017).

Contemporary Angola eventually invites analyses beyond classical accounts of neopatrimonialism focusing on the informalisation of the state and on direct forms of domination through physical violence and coercion (Bayart \& Hibou, 1999; Chabal \& Daloz, 1999). As Hibou (2011) argues when she insists on the 'plasticity' of authoritarian rule, understanding hegemonic regimes requires directing our attention to the subtle effects of obedience and self-discipline emanating from the dominated themselves. This paper pursues this embedding of Gramsci's dialectic of domination and consent through a reflection on the ordinary encounters between city-dwellers and the state in Luanda.

\subsection{Ordinary encounters with the state, or how to study intentionality in a deregulated system}

In an effort to draw new horizons for the anthropology of the state at the beginning of the 2000s, Trouillot (2001) called upon ethnographers to 'insist on encounters that are not immediately transparent [and] revert to the seemingly timeless banality of daily life' (p. 133). The term 'encounter' has since been theorised further. Aretxaga (2003) uses it to describe the entanglement between the 'fear and desire' that the idea of the state inspires:

In the era of globalization, practices of legibility and control are carried by a variety of organizations and take a variety of forms that nevertheless produce state-like effects so that the state continues to be a powerful object of encounter even when it cannot be located [. . .] What is interesting here is that it is not only the people who imagine the state but also the state itself in its multiple incarnations that has, and enacts, its own fantasies. This mirroring dynamic [. . .] produces and reproduces the state as objects of fear and attachment, of identification or disavowal, as subjects of power, elusive, unbea $\neg$ table, ever present, immensely powerful, or impotent. (Aretxaga, 2003, p. 399)

Following Aretxaga, this paper embraces the open-endedness of the idea of 'encounter' and seeks to identify 'state-like effects' in the interstices of formal state institutions. This approach requires acknowledging that 'encountering the state' is not a straightforward process that can be pinned down in a series of ethnographic situations, but rather a 'subjective dynamics' (p. 395) through which the idea of the state comes to life. Encounters are unpredictable and elusive and require a certain openendedness in the analysis itself. 
If, as Ananya Roy (2005) contends, 'state power is reproduced through the capacity to construct and reconstruct categories of legitimacy and illegitimacy' (p. 149), then the concrete episodes during which urban unpredictability contradicts the idea of a regulatory state are particularly informative and open up the question of informality to a broader reflection on power and sovereignty. Following Roy indeed, 'informality must be understood not as the object of state regulation but rather as produced by the state itself ' (Roy, 2005). In this perspective, urban informality is not the result of weak state regulation but rather the product of a 'deregulated system' where the state 'actively utilise(s) informality as an instrument of both accumulation and authority' (Roy, 2009b, p. 81). Ultimately, Roy speaks of 'calculated informality' crafted by the state itself: 'such forms of uncertainty only deepen the political dependence of the rural-urban poor and guarantee their obedience to the project of populist patronage' (Roy, 2009b, p. 81).

By projecting urban informality onto larger questions of domination and obedience, Roy invites us to reflect on the intentionality of the state. Her theory of planning as an instrument used by the powerful to actively produce situations of 'calculated informality' and serve a 'project of populist patronage', indeed suggests that urban systems respond to a strong rationality imposed from above, that is to a political intention or 'intentionality' (Roy, 2009a). In Angola, the inheritance of tightly centralised colonialism associated with 15 years of socialism, renders the question of intentionality particularly relevant. The idea of a powerful state regimenting daily life on the street feeds the perception that, up until today, those in power deliberately maintain a deregulated system where they can set the rules unilaterally and guarantee their personal wealth. However, the very nature of a hegemonic system lies in its capacity to obscure these mechanisms of calculated informality. The first encounter that marks the story of the Monteiros illustrates how the authoritarian state is rebranding itself through a discourse of developmentalism that plants the seeds for acceptance and even thankfulness.

\section{Encounter one, forced removal: facing the omnipotent state}

Narrating the trajectory of the Monteiro family in Luanda since 2002 illustrates how city-dwellers encounter the state and its reconfiguration after the war. From the story of the grandfather ('Avo') to the life of his great-grandchildren, the Monteiros have been exposed to concrete situations of calculated informality that flesh out the ambiguous mechanisms of hegemonic domination. However, their story is not easy to tell; it is manifold and depending on whom I have been talking to, I heard various versions and various interpretations of past events. Less than an attempt to reconstitute a factual trajectory, these pages aim to share a collective narrative that the family tells about itself. 
An important element that characterises the Monteiros is their upward connections with the MPLA. Avo's children do not exactly know under which conditions their father formally joined the liberation movement in the early 1970s. As far as they can remember, he was always a fervent nationalist and a respected figure amongst the Kimbundu patriarchs of his region. ${ }^{3}$ In the 1960s, Avo resorted to exile in order to avoid conscription in the Portuguese army during the war of independence. From that point, his adhesion to the MPLA seems so obvious that it is unquestioned. The installation of the family in a Portuguese villa at the foot of the old colonial palace in Luanda right after independence also contributes to naturalise this partisan loyalty. As a foot soldier of the party that had taken control of the capital, Avo Monteiro logically benefitted from the nationalisation of Luanda's colonial properties in 1975-1976, a common token of appreciation for MPLA partisans at the time, and the beginning of a patronage system that would become more elaborated in the 1980s (Messiant, 2008; Tomas, 2012). Although the story of the Monteiros is necessarily singular, it can be read as an exemplar of how partisan networks and family structures are intertwined in Luanda.

\subsection{Academic writing in an authoritarian context: a note on methods and ethics}

Understanding the entanglement of ideology, patronage and kinship raises questions about the ethics of ethnographic research and questions the balance between in-depth testimonies and protection of sources. The very nature of observant participation implies that although everyone in the family is aware of my position as a researcher - and indeed often inquires about the objectives and outcomes of my work - I also found myself in situations of great intimacy that pushed the limits of informed consent. My presence in some gatherings, unexpected turns in casual conversations, or confessions shared amongst relatives wouldn't have been accessible in another setting. The consequences are twofold. Firstly, it became impossible to ask certain questions. For example, asking how much a house precisely costs or what the trade-off is in the negotiation with a local politician would have been extremely offensive and broken the trust. Instead, I had to conform myself to the discretion expected from any other young woman in the family. I relied on silent observation and sought clarifications about specific events indirectly, through non-related conversations. Secondly, I have to be particularly cautious to protect the anonymity of the testimonies. Hence the nature of the material presented below. Fictive names are only a superficial device. Some information will also necessarily remain vague enough in order to limit the risk of repercussions. For this reason, I will not provide exact details about

\footnotetext{
${ }^{3}$ Although the civil war that opposed the socialist regime of Luanda to the United States backed guerrillas in the interior is better described as a proxy for the Cold War, historians note how ethnic categories were used to naturalise the conflict. As a result, being Kimbundu is associated with supporting the MPLA (Pearce, 2016).
} 
the position of the members of the family vis-à-vis the party or about the localisation of their homes. This is not uncontroversial but it might be the most ethical way to write about the inner work of political domination without (hopefully) putting anyone in danger.

\subsection{Evicting MPLA's foot soldiers: the iron fist of the presidency}

Avo Monteiro received the keys of his old house in 1976. At that time, the streets of the bairro were tarred and lit at night, every house had access to water and electricity. But conditions soon deterio $\neg$ rated. Brutal decolonisation, lack of capacity and of course civil war limited the ability of the MPLA to deliver basic services. Moreover, the formal adoption of Marxism-Leninism in 1977 translated into the regimentation of social life by party structures (notably in terms of food provision, basic education and public information), while feeding a chaotic parallel market for basic domestic items (food, hygiene products, school materials, and so forth) (Birmingham, 2015; Messiant, 2008; Morice, 1986).

Avo Monteiro became the rock in the midst of these deteriorating conditions. He held the family together. When his grandchildren remember the 1980s, they evoke fond memories ofthe old villa that was their refuge when they were playing truant. Around them, the city was changing dramatically. Hundreds of thousands ofpeople displaced by the warsettled in, but the villa was a stronghold, an anchor of resilience, where the family would gather for meagre - but nonetheless festive - lunch on Sundays.

The global geopolitical ruptures of the early 1990s brought change to Angola: the MPLA started its transition towards a market economy and multipartism. Politically the transition was disastrous - the country soon plunged into another decade of war; economically, it proved quite profitable for the elite (Ferreira, 1995; Messiant, 2008; Pepetela, 2012). In Avo's bairro, the so-called 'liberalisation' meant the resurrection ofanold colonial project. The whole areawas earmarked to become the political centre ofthe capital, concentrating major state buildings. In 2001, a presidential decree ordered the demolition ofAvo's house. Usual recourses proved vain: neither the old members of the MPLA living in the area, the neighbourhood committee (that is, in fact, a local branch of the MPLA), nor the local administration had visibility into the project. The 'New Political and Administrative Centre' project is entirely managed by the Office of Special Works, a body under the direct authority of the Presidency that circumvents all state structures (Croese, 2017). A simple presidential order approved by the Cabinet was sufficient to exclude five central bairros from regular urban management. The network of groundlevel bureaucrats and politicians to which Avo had access through his affiliation to the MPLA was left out of the game. 
The eviction of the Monteiros indicates deep alterations in the patronage structure. The relative position of privilege that the family had felt after independence for being members of the MPLA was fading away. Their loyalty to the party was not enough to shield them from the hard power that was now concentrated in the hands of the Presidency. Avo thus symbolises the first generation of MPLA foot soldiers who once shared the anti-colonialist ideology of their party and got sidelined as the discourse of reconstruction and developmentalism imposed new governing bodies that curtailed wartime patronage networks.

\subsection{Rehousing in Panguila: the velvet glove of the developmental state}

Avo didn't live to see the bulldozer taking down his house. His kids were allocated a house in Panguila. Helena recalls her arrival in the rudimentary two-bedroom house, standing on bare lands. 'When they took us out, oh I cried [. . .] I really cried, I lost weight. I didn’t want to stay here. [. . .] Bush! Bush, bush, bush! Up to the entrance of the street!'.

The reference to the 'bush' (mato) is explicit: the forced removal transformed old urban dwellers such as the Monteiros into outcasts. The house in Panguila could not compensate in any way for the old colonial villa. It nevertheless represented a certain advantage in a context where so many evictions are plain brutal demolitions without rehousing (Amnesty International, 2003; Development Workshop, 2005; Human Rights Watch, 2007). Avo's children don't know why their family received compensaᄀtion when so many other city dwellers were just chased away from their homes by police forces. A probable explanation lies in the timing of the event.

Inthe early 2000s, the MPLAwas at a critical juncture of history. Ithad managed to retain its domination in the transition to multipartism in the 1990s, but with the war coming to an end, it now needed to rebrand itself from a victorious belligerent to a normalised democratic ruler. The brutal demolitions that started to mushroom in the 1990s were not sending the right message out (Gastrow, 2014). In this context, the inauguration of Panguila in January 2003 participated in building the image of a developmental state. Sylvia Croese (2017) studied this strategy in detail. Reconstituting the organogram of the institutions in charge of state-led housing projects in Luanda, Croese highlights the progressive centralisation of develᄀopmental projects around the President of the Republic, out of the reach of regular state institutions. Both the destruction of Avo's bairro and the construction of Panguila illustrate the effect of these 'parallel structures' that 'ensure that certain strategic goods and investments are delivered effectively', but con $\neg$ tribute to undermine the authority of the regular state (Croese, 2017, p. 90). In this perspective, the forced removal of the Monteiros indicates that the new 
'developmental' agenda not only reshuffles interpersonal topographies of political influences, it also recasts the general idea of who and where the state is.

Looking closer to Panguila helps to characterise this new idea of the state. After the first 300 houses delivered by the Office for Special Works in 2003, the settlement continued to grow. Avoiding the words 'emergency housing' or 'resettlement', the government started to speak of 'social reinsertion' and publicised Panguila as a benevolent public housing project rather than as the legal compensation owed to those it had evicted in the city. The example of a show-house in Panguila illustrates the concrete means used to build a new legitimacy (see Figure 1).

The accumulation of 'institutes', 'programmes', and 'offices' constructs the image of a ubiquitous state responding to the developmental needs of its citizens. The operation of legitimisation works both internally and internationally. Internally, the government seeks to gain domestic support by assisting ex-combatants, the destitute, or people living in risk areas even if, in practice, the actual criteria of attribution remain opaque; internationally, it courts foreign partners and development agencies by adopting their buzzwords. Panguila is typical of 'pro-poor policies' promoting 'slum eradication' through the provision of 'affordable housing'. The new lexicon - and its physical display on site - is a good indication of the nature of the process: branding matters at least as much as actual delivery and showing short term quantitative outcomes is more important than sustainability or civic participation.

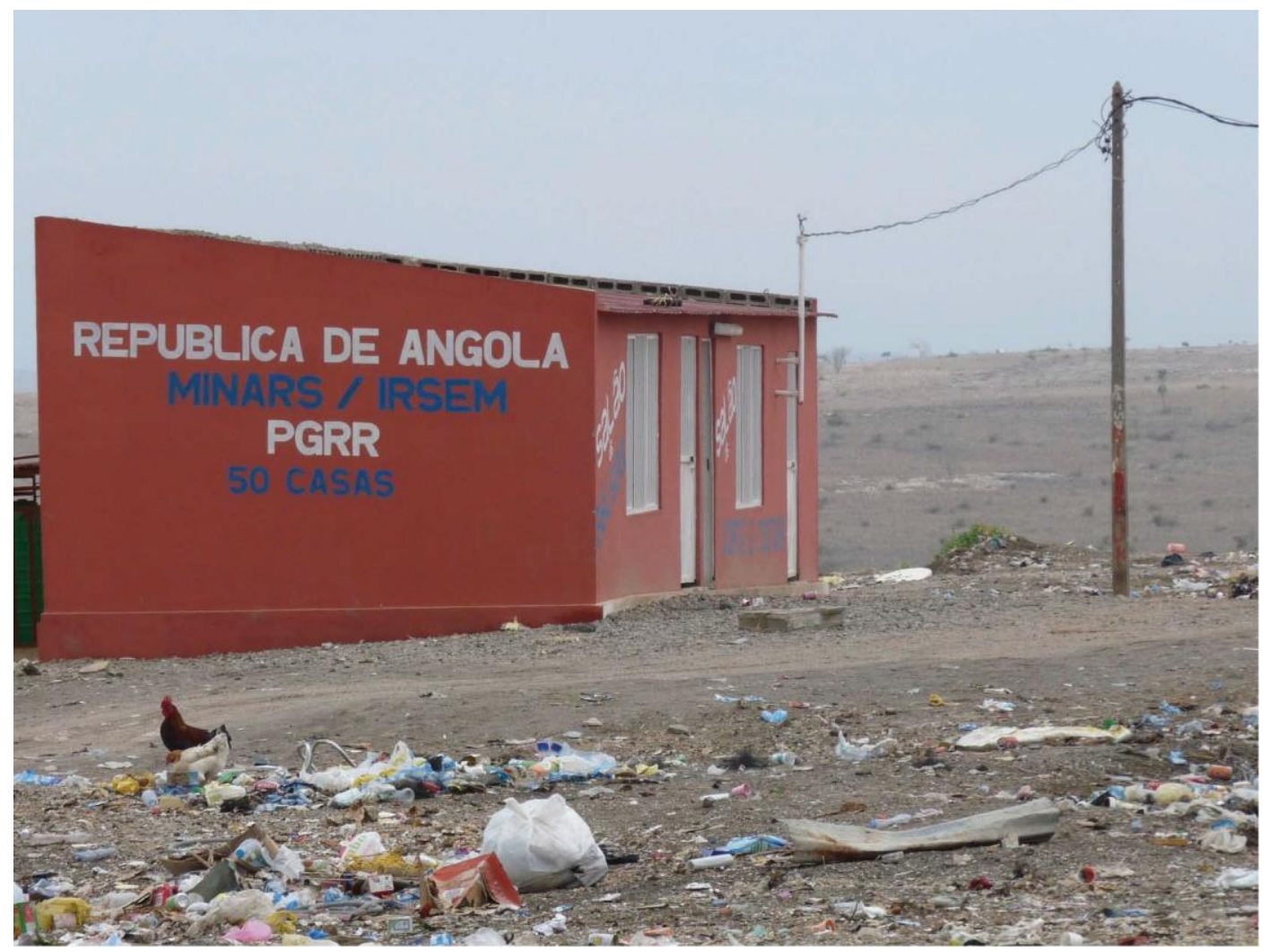


Figure 1. The Ministry for Assistance and Social Reinsertion (MINARS) advertises the delivery of 50 houses in Panguila.

Notes: The multiple acronyms painted on this show-house illustrate the multiplication of state institutions whose respective roles are often obscure (IRSEM: Institute for the Socio-Professional Reinsertion of exCombatants - created in 1995; PGRR: Government Programme for Reinforcement and Reintegration launched in 2009). Source: Author, October 2012

The rehousing process eventually illustrates the ambiguity that characterises the Angolan state after the war. While the demolition of the house can be read as the iron fist of the Presidency that no longer needs to nurture the historical constituency of its party, the rehousing comes as an unexpected velvet glove summoning a new discourse of developmentalism. Between deliquescent urban services and new housing projects, between raw power and welfare, the Monteiro family faces an omnipotent ruler whose decisions are definitive. The encounter leaves no room for negotiation and the multiplication of state agencies and special bodies reinforces the sense of arbitrariness. Historical networks of patronage built up since the early days of independence are lost in a maze of ill-identified institutions. In this interpretation, the state is finally everywhere and nowhere at the same time, making it impossible to hold anyone accountable and confirming Roy's hypothesis of a state that deliberately maintains a deregulated system.

\section{Encounter two, consolidation from below: alternative sites of authority}

Christian Lund (2006) speaks of 'twilight institutions' to describe 'the multiple parallel structures and alternatives sites of authority" (p. 689) that challenge the description of "the "state" as a coherent institution' (p. 686). For those who were thrown in Panguila in the early 2000s, daily life undoubtedly developed 'in the twilight between state and society' (Lund 2006). While they officially received their house from the powerful Office of Special Works, they were mostly left to their own initiative when it came to attend to basic needs like water and electricity provisions, schooling, or even policing. In that sense, the second encounter that I describe below shows how the state becomes invisible in citizens' daily life.

As a matter of fact, Panguila was never planned as an integrated city. The minimalist infra-structure built in 2003 broke down with the growth of the settlement. ${ }^{4}$ The mosaic of state agencies involved

${ }^{4}$ During my stays in 2012, 2013, and 2014, I witnessed structural improvements in sector one: street lights were installed and roads were tarred. These amenities were, however, still lacking in the rest of the settlement. 
became more elaborate, the number of on-site constructors multiplied. In this context, it is virtually impossible today to retrace the exact chronology of the development or the detailed organogram of stakeholders. The role of the Office of Special Works, and of its offspring, the Office of National Reconstruction, is particularly opaque. One of their close partners, the Lebanese consultant Dar-alHandasah, did present a master plan for Panguila, described on its. website as 'an attractive and healthy environment, consisting of open spaces, gardens, parks, and landscaped streets' (https://www.dar.com/, accessed in September 2012). However, the plan has since been taken off the website and the whole project eventually seems to have developed without a clear unitary vision.

For the inhabitants, the lack of transparency results in rumours and cynicism about the purpose of some sections. Helena, for example, took me to a group of houses known as 'the Brazilian houses'. They are fenced off from the rest of Panguila and Helena affirms that they have remained empty since their construction. Not far from her place, other houses were never completed, 'it was supposed to become a school'. The same uncertainty surrounds a large empty plot that lies in the middle of the settlement. Helena thinks that it is reserved to build a hospital but at the moment, the plot serves as a dumpsite. The only map of the settlement available to the public is a plan drawn by a Chinese constructor. It is hanging in the office of the representative of the Ministry of Construction for Panguila (see below). As I asked whether the plan represented the existing layout of the settlement or a projection of what it would look like in the future, the officer shrugged. He doesn't read mandarin, how was he supposed to know?

Despite the official branding of Panguila as a state-led project, leadership isn't felt on the ground. On the contrary, the inhabitants are left to their own devices. In sector one, Avo's house might have fallen apart if it wasn't for the Monteiros personal investment in extra cement to stabilise the plot and fill-in the cracks that appeared in the walls soon after they moved in. The reality of this urbanisation from below contributes to demystify the state. Firstly, the physical precariousness of the settlement discredits the idea of a powerful ruler dictating where and how people should live; secondly, the social consolidation of neighbourhoods gives rise to 'twilight institutions' that constitute 'popular responses to political and economic disorder, and an exercise of accountability at the local level' (Lund, 2006, 688), and hollow out the idea of the state as a coherent, overarching institution.

\subsection{Making home: when the state becomes invisible}

Panguila redefined the borders of the city; it reshaped the relationship between centre and peripheries, and created new forms of socio-spatial differentiations through which the Monteiros would now navigate in order to access the state (Buire, 2014; Udelsmann Rodrigues, 2009). 
After Avo's death, the family designated Helena to take care of the house in Panguila. At the beginning, Helena's responsibility was simply to maintain the house and prevent its occupation by strangers as often happened at the time. For a few years, she kept commuting between Panguila and her siblings' homes in the city. She often only came to the suburban house on weekends. But as more houses were built, Panguila became more attractive. In the centre, the real estate market skyrocketed under the pressure of oil-driven expatriates' influx. A two-bedroom flat in town could be rented for about USD 6,000 per month; by comparison, a new house on a large plot in Panguila could be bought for less than USD 15,000, a real opportunity for aspiring homeowners.

Helena and her siblings progressively turned the house into a home: they fenced the plot, bought an electric generator and installed a water tank in the yard. Helena moved in with her three children and, along with her sisters, invested in catering equipment in order to run their own business in Panguila. They built an extra room at the back, doubling the living space. These alterations took place gradually, depending on the funds available. In 2012, most of Helena's neighbours had accomplished the same kind of work. The fences erected to delineate individual properties marked the separation between private and public space. Trees planted in front of the houses provided shade and a certain sense of urban landscape. When asked whether she would like to go back to the city, Helena burst out in laughter: 'The city is already coming!'

As a matter of fact, with the 11th sector currently under construction, Panguila is now recognised as a suburban area in a sprawling metropolis. The segregation once felt by Helena is replaced by the pride of being one of the few original residents. Last but not least, investing in the house gave the Monteiros privileged access to the housing market that started to flourish in Panguila in the mid-2000s. Helena's brother-in-law managed to buy his own house in 2004 and then acted as a broker for the whole family. Helena's sister explained to me what she understood to be 'the rules of the game'. The trick lies in negotiating directly with the constructor. If a public agency orders 100 houses for a specific re-housing programme, the role of the brokers is to obtain 50 more to be built on the same budget (hence the poor quality of the houses). These 50 extra houses are distributed amongst local big men long before the new section is even completed and feed the parallel market. Engineers, architects, officers, members of the ruling party, or simply influential neighbours: all the players get their share. In this market, the asset is not limited to the product finally delivered, it also lies in the different stages of the brokering chain. The personal connection one is able to maintain with the other players is key. Housing transactions actively build the community by creating local networks of dependency and reciprocity. Nowadays, the Monteiros own a total of nine houses in Panguila. Each house came about from a specific negotiation whose details were difficult to reconstitute as several houses changed hands while 
I was still doing fieldwork. A house that I thought belonged to a niece was eventually sold outside the family; a nephew who had settled in a comfortable house suddenly moved to a new unit where he started all the basic alteration works over again. I realised that there is no generic scenario in those sales. Each transaction appeared as a good opportunity seized by a family member at a given time rather than the result of a long-term strategy. In this flexible game, what makes the difference for the Monteiros is their ability to put their capital in common: socially, they are able to mobilise a large network, mainly thanks to the personal network of Helena's brother-in-law within the party (see below); economically, the cousins are used to contributing to collective expenses (from paying university fees to investing in a house); in terms of information, lastly, the whole family collects the rumours that, once verified, can become strategic leaks indicating the next move to be taken.

This strategic use of family networks is evident in the role of Helena in Panguila's housing market. Although she cannot afford to buy a house for herself, Helena has turned the housing transactions into a direct source of income. She follows the houses entering the market and basically sells her insights to aspiring investors. New buyers for example pay her to 'take care' [tomar conta] of their house for the time they negotiate their title deed in Angola's arcane land administration (Cain, 2013a). 'Taking care' covers a wide range of practices, from negotiating surveillance with the neighbours to directly moving into the house or subletting it to a trusted tenant. Helena is obviously not the only one on this scene of pre-sale or rental agreements. Scandals regularly erupt when these informal transactions aren't settled amicably (Bambi, 2012a, 2012b).

Panguila is the product of a classical process of incremental urbanisation. I argue that this consolidation from below represents an encounter with the state that questions both its omnipotence and its intentionality. To put it in Roy's words, the Monteiros experience first-hand the reality of 'deregulated system' where the state eventually appears rather incapable of 'purposive action and planning'. In contrast with Roy's assertion that deregulation is a tool for state domination however, the Monteiros are not mere victims. The interference of the Office of Special Works and the messiness of the state machinery allow them to 'play the game' and reclaim a certain control over the old resources that had failed in the centre at the time of the eviction, especially through residents' committee and local MPLA structures.

\subsection{Twilight institutions in Panguila: outside the state but inside the party}

Since its inauguration in 2003, Panguila has officially been administered by a special commission of the Ministry of Construction. In June 2011, Luanda's provincial government announced the end of this 
regime of exception: the Ministry was to hand over Panguila to the municipal authorities of Cacuaco ${ }^{5}$ (Portal do Governo, 2011a), but a territorial reform adopted in Parliament a few weeks later (Law 29/11) rendered the decision obsolete. Panguila was now incorporated into the province of Bengo and its official administrative home was the rural municipality of Dande (Portal do Governo, 2011b). The members of the residents' committee I met in 2012 criticised this decision: they had spent years building a working relationship with officers from Cacuaco, they were not willing to do it all over again with Dande. The reaction of the Ministry seemed more pragmatic: it nominated an officer to be present on-site twice a week. When I visited this special representative in September 2012, the man didn't pretend to be close to the residents. To him, most people living in Panguila are poorly educated urban squatters; the very fact that they were evicted from the city proves that it is useless to consult them on any urban matters and that the ministry knows what is best for them. In terms of quantitative management, his estimations were vague. He suggested a total of around 13,000 inhabitants in Panguila. The register held by the residents' committee at the time reflected over 60,000 inhabitants. ${ }^{6}$ The discrepancy between decisions taken at the provincial level and national territorial reforms, or between ministerial figures and statistics collected on the ground are symptomatic of the disconnect of regular state institutions when it comes to actual urban management. Even when it tried to normalise Panguila's regime of exception, the state failed.

In this context, the development of alternative institutions that circumvent official state institutions can be seen as a pragmatic response to the impossible tasks assigned to both a rural municipality and the central ministry, confirming Roy's argument that informality is a mode of urbanisation in itself.

Residents' committees are the main structure regulating daily life in Panguila. A study realised by the NGO Development Workshop showed that documents delivered by the residents' committee are widely - though wrongly - perceived as a legal guarantee of one's rights (Cain, 2013b; Development Workshop, 2011). Croese (2015) retraces the history of these committees from local associations channelling anti-colonial mottos before the independence to their recuperation by the one-party state as a formal tier in local government inthe 1980s. Developing the caseofZango, another re-housing site in Luanda, Croese describes how the committees were formalised by local authorities in the 2000s but never officialised by the central state, making them a perfect example of 'twilight institutions'. As summarised by one of Croese's inter $\neg$ viewees, residents' committees are 'inside the government but

\footnotetext{
${ }^{5}$ Angola national territory is divided in 18 provinces, each province is subdivided into municipalities. Luanda is a province and has been divided into seven municipalities since July 2011.

${ }^{6}$ The latest figure published by the government is now close to 80,000 (Angop, 2014).
} 
outside the law' (Croese, 2015,p.407).Croese shows the consequent tensions that arise as the presidents ofthe committees are meant to actas brokers in an ambiguous triangle: they have to defend the interests of the residents but are not entitled to any kind of municipal resources, all while displaying their loyalty to the local structures ofthe party. My own experience in Panguila confirms this close conjunction between the MPLA, the residents' committees and - to some extent - the local government. The invisibility of the state can thus be interpreted as the replacement of the state by the party.

I followed Pedro, the secretary of one of Panguila's residents' committees, over a couple of days and can testify of the legitimacy given to his work by the residents. To explain what his mission entailed, Pedro started by opening the heavy book where he registers the residents. Residents later told me that he is the bookkeeper for the settlement: if your name is on the register, he can issue an attestation of residence on letterhead paper or put his stamp on your sale contract. Pedro then took me to a tour of his sector. Walking with him was an interesting experience as people suddenly became much more interested in my presence in Panguila (or were they more suspicious?). Some neighbours called Pedro to inquire about me. Others on the contrary closed their doors when they saw us. Both reactions illustrate the symbolic power of this man. When I walk with the Monteiros, the only reactions we receive are neighbourly greetings.

That being said, Pedro was not parading. He was actually conducting a door-to-door campaign to register disabled residents on behalf of Bengo's provincial government, a surprising task for someone who openly confessed his aversion for the politicking that followed the administrative reshuffle of 2011. But Pedro is pragmatic, he wanted to get it done before the political rally organised by the MPLA the week after, where he expected to meet the officer in charge of the report. Whatever sentiments one may hold towards the current leadership of the party and of its local branches, being part of the residents' committee requires cultivating a good relationship with the MPLA. In fact, during our walking tour, Pedro introduced me to two prominent local politicians. The president of the local branch of the MPLA was enchanted to meet me. To illustrate his dedication for his community, he detailed to me his intention to summon a Chinese constructor working nearby to come for one day and lay red earth on the main road before the rainy season. He wanted to stabilise the access to his neighbourhood and cheekily added that the new road could come up to his own gate. Pedro also introduced me to the local coordinator of the MPLA women's league (OMA). When she learnt that I speak French, the woman shared with me stories from her early political career in Kinshasa in the 1980s. For both leaders, local politics is deeply connected to a broader context of authoritative patronage and inseparable from the ideological trajectory of the MPLA. 
From the 'administrative regalia' associated with the register to the ambiguous relationship with a government that doesn't recognise its existence but calls for its support, the residents' committee eventually presents all the features of an 'apparel of public authority' (Lund, 2006, p. 690).

While the practical elements of governance - the allocation of resources, administration of rights, appointments to office, authorization of certain practices - are crucial, it is when they combine with the symbolic language and choreography of governance and its props in terms of contracts, deeds, attestations and so forth that the compound makes up the state. (Lund, 2006, p. 690)

More precisely in Luanda, the 'symbolic language and choreography of governance' are unambiguously that of the MPLA, as the short encounter with two local leaders illustrated during my walk with Pedro. Even in the absence of formal state institutions, the party remains at the core of the daily governance of Panguila.

The triangle residents' committees/local and central government/ruling party eventually characterises an elusive encounter that might not be based on regular state institutions but nevertheless reveal genuine 'desires for State, protection and justice' (Hibou, 2011, p. 12, author's translation). As we saw with Pedro, actual practices of governance from below are contained within the local structures of the ruling party. If the uncertain boundaries between what is legal or illegal, legitimate or abusive, create the idea of an elusive state that city-dwellers cannot locate, the omnipresence of the MPLA on the contrary contributes to a strong 'imaginary of the state in which desire and fear are entangled in a relation of misrecognition from which one cannot be extricated' (Aretxaga, 2003, p. 407). The idea that one 'cannot be extricated' from the web of influence of the ruling party becomes clearer when we look at the relationships within the family itself.

\section{Encounter three, intimate politicks: the family hijacked by the party}

Lund (2006, p. 689) insists on 'the irony' that there is when 'the institutions which challenge the state' actually contribute to propelling the idea of the state. In Panguila more specifically, we observe how the idea of the party-state takes over all sources of authority (either formal state structures, special Presidential institutions, or residents' committees), leaving residents with no other option than to resort to partisan networks that failed them in the past. In this context, the hypothesis formulated by NavaroYashin (2002, p. 5) in the Turkish context appears particularly relevant: 'cynicism' might actually be 'a central structure of feeling for the production and regeneration of the political'. Navaro-Yashin (2002, p. 4) insists that it is not 'a lack of consciousness about ideology or discourse' that 'reconstitutes and regenerates state power', but 'unconscious psychic attachments' that belong to the realm of 'fantasy'. 
The third encounter I describe below seeks to locate the 'fantasy' of the party-state as it is experienced in the Monteiro family. If the public marketing that surrounds Panguila suggests that the primary element of this fantasy relies on the personification of the state through President dos Santos' cult of personality, the infiltration of the partisan discourse of the MPLA in ordinary life is much subtler. It is as an intimate process where political discipline pervades the family itself. Zooming in on an ordinary gathering of the Monteiros in Panguila illustrates the impossibility, in a hegemonic system, to draw a line between the personal and the political, to delimitate what is 'outside' the reach of the dominant group, or to identify a supreme source of authority beyond the individual. A Sunday lunch at the Monteiros eventually appears as the essence of the silent fabrication of consent in post-war Angola.

\subsection{The spectacle of the state: from personification to personalisation of power}

In May 2013, official news agency Angop reported on a press conference held by the Minister for Construction to announce the construction of 1,350 houses in Panguila. The short piece of news does not give much detail about the financial or material responsibilities behind the project; it literally mentions 'an unspecified budget' that came out of the Public Investment Programme of $2013 .{ }^{7}$ In the conclusion, however, the journalist describes the visit President dos Santos made to 'traditional authorities' in Bengo province, 'to whom he gave miscellaneous goods' (Angop, 2013a). A few months later, the same news agency related the ceremony launching the construction works. Once again, the article is based on the declaration of a member of government - this time the state secretary for Construction. Though President dos Santos was not present during the ceremony, the journalist quotes the state secretary saying: 'During his last visit to the Bengo province, the chief of the government, José Eduardo dos Santos, took good note of the important challenges faced by the population in terms of housing' (Angop, 2013b).

This rudimental news clipping illustrates how Panguila has become a site for the spectacle of the state (Debord, 1996). National media ensures the staging. In accordance with the script of the developmental state, the story consists of government officials announcing the delivery of goods to a population in need. Unsurprisingly, the scenario eludes questions of accountability or criteria of attribution. The only clear figure that comes out of the encounter is that of President dos Santos, the generous big man who hands over presents to the people and listens to their problems.

\footnotetext{
${ }^{7}$ The Public Investment Programme is a portfolio of the Ministry of Planning and Territorial Development created in 2010. It opens special credit lines for local projects, but here again, the opacity of the stakeholders makes these lines virtually untraceable.
} 
The discrepancy between the opacity of the government (what are the respective roles of the minister, the state secretary, provincial authorities?) and the crystal clear image of the president as a caring leader constitutes the plot of the spectacle. Less than a piece of information about a specific public expenditure, these articles are a manicured representation of the president in the most classical sense of a 'big man': he does not rely on a formal structure but is able to 'transform social relations into strategic power and control' (Utas, 2012, p. 8). I argue that this is not just a screenwriting technique personifying the Angolan state as José Eduardo dos Santos, but a systematic process of inscribing political authority onto the most intimate encounters. The personalised relationship to power and authority is not only staged around President dos Santos, it is a fundamental mechanism of politicisation deeply embedded in the daily lives of Angolans.

\subsection{Intimate political encounters within the family}

My immersion with the Monteiros in Panguila reveals how decisions related to daily urban life, like renting a house or building an annex, are woven within the hegemonic domination of the MPLA.

The typical setting for this encounter is a lunch in a courtyard on a hot Sunday afternoon. Since the destruction of the old house in the city and the passing-away of Avo Monteiro, Sunday lunches are usually held at Maria's place in Panguila. Maria and her husband transformed the original twobedroom plan into a comfortable villa. They added a reception room at the front, built various annexes at the back and grew a food-garden, but the most appreciated place is the shady front yard where they host family gatherings. Maria's sisters, daughters, and daughters-in-law bring pots of food; the men buy drinks for everyone. The teenagers are sent up and down to the corner shop to buy a pack of cigarettes or a kilo of manioc flour. When everyone has arrived, when the beers are ice cold, and the pots served on the table, the conversation is already animated. Women tease each other for their sweaty faces after preparing the traditional funje (manioc flour paste), children try all their tricks to get another bottle of Coke or Fanta, men debate over their latest phone. . At one stage or another, the conversation inevitably turns to the question of 'the houses'. How much would it cost to repair the roof over the old annex in sector one? Did Helio receive the approval of the residents' committee to build his garage? Cisco and Cristina are looking for a three-bedroom in Panguila, does anyone know of a house for sale? Gomes was offered a course abroad for six months. His wife is thinking of renting out their house; she could stay with Helena in the meantime, how much would she get for their two-bedroom? Everyone brings his or her own experience: one knows of a Chinese warehouse selling cheap corrugated iron, another recalls having a fight with tenants after renting out a house for a short term. Questions of official authorisations and evaluations of the market are generally referred to Maria's husband. He is 
the most influential man in the family, the pai grande ('big father') who replaced Avo in the role of patriarch. Most of all, as a long-standing member of the MPLA, he has a direct access to party leaders in Panguila. His voice can summon small officials or nagging representatives of residents' committees. His potential access to confidential information undoubtedly plays a big role in the family's successful housing transactions. As any elder, he is deeply loved and respected but he is also feared. Pai grande can arrange a house for you, but he can also foreclose the transaction if you break the rules. He might help you out of a tricky situation, but you better make sure it won't happen again. The line is thin between support and disgrace.

Pai grande is a great storyteller. He often ends the day surrounded by his sons and nephews, mostly men. When pai grande speaks, everyone listens silently and slowly drifts back to a time when the party and its foot soldiers were sharing the same goal of independence, liberation, and socialism. Pai grande tells anecdotes from the war against the Portuguese, or from his years spent in Kinshasa in the early days of Zaire. In his stories, the MPLA is the great party standing in defence of human dignity; it is an object of pride and honour that anyone should bow to (starting with his own children and grandchildren). Pai grande is nostalgic of the good old days.

He knows that for his grandchildren, the MPLA is an estranged clique immersed in its internal politicking and incestuous alliances. When a young nephew breaks the popular joke about the daughter of the president who supposedly became the first millionaire woman in Africa after selling eggs on the street, pai grande doesn't reprimand. In a resigned shrug, he ignores the mockery but the silence that follows leaves everyone slightly uncomfortable.

However, the electoral appeal of the MPLA doesn't matter much at the Monteiros' table, for whether they like it or not, the party remains their major asset. Everyone is aware that the relative prosperity of the family would not have been possible if they - as a family - were perceived as enemies of the party. Pai grande doesn't need to convince anyone: the family belongs to the MPLA, or as the old slogan goes: 'The MPLA is the people. The people is the MPLA'. This unquestioned alliance crosses generations. One of the cousins confessed to me that, despite the fact that he personally rejects the oligarchic regime in place, he had to be 'reasonable' when the time came to cast his ballot at the general elections of 2012.

With his MPLA-stamped shirts and caps, pai grande is not just a member of the party; he is the party. Sitting down with him is the ultimate encounter that the Monteiros have with the state. The Monteiros can't be described as foot soldiers of the MPLA anymore. The youth don't adhere to the ruling party, but they still consent to its domination, in an impalpable and silent manner that is hard to seize from outside. 
In this perspective, the contemporary idea of the state in Angola cannot be reduced to an omnipotent developmental state that builds and destroys, nor to an elusive state that flickers between the shadows of twilight institutions. These encounters eventually portray a fragile state enmeshed in a strong party where the fantasy of a centralised source of power embedded in the persona of José Eduardo dos Santos trickles down to the youth of Panguila through their uncles and grandfathers. There is no intentional domination clearly directed from the top but rather a web of pragmatic acceptance that is experienced as family solidarity before anything else. Sunday lunches in Panguila are no political rallies. They are genuine family gatherings, where siblings socialise joyfully. Sometimes, a particular issue requires a direct intervention of pai grande in his networks. The discussion is pragmatic. But this is never the climax of the day, just one of many animated conversations. The day usually ends as it started, in laughter and promises to meet again as soon as possible.

Family life eventually shows how the encounter with the party-state is embedded in mundane interactions. The influence of pai grande in his family is a fractal reflection of the personification of power concentrated on dos Santos at the national level. I argue that proximity and even intimacy are crucial to understand the third mode of encounter through which the Angolan state is performed nowadays; an encounter based on an idea of immediacy that abolishes the notion of limits and exteriority. In this perspective, the party-state is never outside of anyone's life, even when it is experienced in confrontational or elusive encounters.

\section{On intentionality, conclusive thoughts in response to Ananya Roy}

In her critique of the notion of informality, Ananya Roy suggests that deregulated systems are the product of 'calculated informality'. In the last 10 years, Roy has shown how planning regulation in India is an instrument in the hands of the political elite to entrench its own interests and privileges. But she goes a step further by affirming that 'the state itself is a deeply informalized entity' in the sense that it 'is able to place itself outside the law in order to practice development' (Roy, 2009a, p. 81). Though I understand - and actually share - Roy's concern about deconstructing the ideological bias that associates the notion of informality to that of powerlessness and marginality, I intended throughout the paper to further question the intentionality of the state. By referring to 'the state itself', Roy contributes to the myth of the state as a coherent unit that can be seized 'outside' ordinary social life. The trajectory of the Monteiro family in Luanda since the end of the civil war instead suggests that the idea of the state is changing over time and space, only acquiring meaning through contextual encounters. 
The first encounter revealed the conversion of an old clientelistic system into a developmental state that tightened itself around the presidency and lost touch with its foot soldiers. The demolition of Avo's house and the removal of his family to the bare lands of Panguila represent a direct confrontation with a single source of authority that corresponds to Roy's idea of a strong state 'able to place itself outside the law in order to practice development' (Roy, 2009a, p. 81).

However, the second encounter was elusive and contradicted the omnipotence of the state. The slow consolidation of Panguila echoed the ambiguous planning practices observed by Roy in India. The development of twilight institutions such as the residents' committees blurs the boundary between government plans and citizens' initiatives. The state becomes elusive, its regular institutions can't be identified and its intentions are untraceable. Surreptitiously, it is then the ruling party that provides the language and symbols of public authority.

The third encounter contends that this dissolution of intentionality finally guarantees the reproduction of hegemony. Roy's idea of 'purposive action and planning' doesn't capture the subtlety of consent and obedience. In the case of Angola, it fails to acknowledge that the state is indistinguishable from the party and that it is not an external organ acting in a world of bureaucracy and (de-)regulated institutions. On the contrary, the third encounter narrates the internalisation of authority on a daily basis. If the Monteiro cousins are way too connected to a world of digital insurgency to be impressed by the blatant cult of personality staged on national media, they are nonetheless subtly submitted to the control exercised by the ruling party at an intimate level. Political domination takes the form of a paternal figure one has lunch with on Sundays. In this sense it is performed much closer to their heart than any state propaganda could ever be and is much harder to dismiss. Consent becomes a matter of genuine care and respect. The vertical intentionality of the state can thus be reframed as a web of horizontal consent. Intimacy and familiarity might well be keys to understand Angola's current political economy.

\section{Acknowledgements}

This paper is based on data collected thanks to a postdoctoral fellowship at the University if the Witwatersrand, in the School of Architecture and Planning (2012-2013). It benefited from several travel grants from the French Institute in South Africa (IFAS) and the French Embassy in Angola. My gratitude goes to my colleagues at the Centre for Urbanism and the Built Environment Studies (CUBES) for the rich discussions, to Brad Safarik for proofreading the final manuscript, and to the two anonymous reviewers from Journal of Development Studies who definitely contributed to sharpen 
the focus of this work. Any errors and weaknesses in the conclusions presented here are my sole responsibility.

\section{Disclosure statement}

No potential conflict of interest was reported by the author.

\section{References}

Agualusa, J. E. (2009). Barroco tropical. Lisbon: Don Quixote.

Amnesty International. (2003). Angola: Expulsées forçadas em massa em Luanda. London: Author. Amundsen, I., \& Abreu, C. (2006). Civil society in Angola: Inroads, space and accountability. CMI Report, R 2006: 14. Retrieved from http://www.cmi.no/publications/publication/?2411=civilsociety-in-angola-inroads

Angop. (2013a). Executivo projecta novas habitações para o Panguila. Retrieved from http://www.portalangop.co.ao/angola/pt_pt/ noticias/economia/2013/4/21/Executivo-projectanovas-habitacoes-para-Panguila,9f71ae8d-55f4-4c12-aaa9-86815dca5868.html

Angop. (2013b). Bengo: Panguila e Sassa Cária ganham mil 350 novas residências. Retrieved from http://www.portaldeangola. com/2013/10/bengo-panguila-e-sassa-caria-ganham-mil-350novas-residencias/

Angop. (2014). Bengo: População do Panguila quer melhoria das vias estruturantes. Retrieved from http://www. portalangop.co.ao/angola/pt_pt/noticias/sociedade/2014/4/21/Bengo-PopulacaoPanguila-quer-melhoria-das-vias-estru turantes,e47fa30d-9016-4b67-83bf-2bf32bd48cfa.html

Aretxaga, B. (2003). Maddening states. Annual Review of Anthropology, 32, 393-410.

Bambi, A. (2012a). Populares ocupam casas do Panguila à força. O Pais. Retrieved from http://www.opais.net/pt/opais/ ?id=1657\&det=25776\&ss=panguila

Bambi, A. (2012b). Panguila ainda com três famílias em cada casa. O Pais. Retrieved from http://www.opais.net/pt/opais/?id= 1657\&det=28767\&ss=panguila

Bayart, J.-F. (2006). L'Etat en Afrique : La politique du ventre. Paris: Fayard.

Bayart, J.-F., \& Hibou, B. (1999). The criminalization of the state in Africa. Suffolk: James Currey Publishers.

Birmingham, D. (2015). A short history of Angola. London: Hurst. 
Buire, C. (2014). The dream and the ordinary: An ethnographic investigation of suburbanisation in Luanda. African Studies, 73,290-312.

Cain, A. (2013a). Angola: Land resources and conflict. In J. Unruh \& R. C. Williams (Eds.), Land and Post-conflict Peacebuilding (pp. 173-200). Abingdon: Earthscan.

Cain, A. (2013b). Luanda's post-war land markets: Reducing poverty by promoting inclusion. Urban Forum, 24, 11-31.

Chabal, P., \& Daloz, J.-P. (1999). Africa works: Disorder as political instrument. Oxford: James Currey Publishers/Indiana University

Press.

Corkin, L. (2013). Uncovering African agency: Angola's management of China's credit lines. Burlington, VT: Ashgate Pub Co.

Croese, S. (2013). Post-war state-led development at work in Angola: The Zango housing project in Luanda as a case study (Unpublished doctoral dissertation). Stellenbosch University, Stellenbosch.

Croese, S. (2015). Inside the government, but outside the law: Residents' committees, public authority and twilight governance in post-war Angola. Journal of Southern African Studies, 41, 405-417.

Croese, S. (2017). State-led housing delivery as an instrument of developmental patrimonialism: The case of post-war Angola. African Affairs, 116,80-100.

Das, V., \& Poole, D. (2004). Anthropology in the margins of the State. Comparative ethnographies. New York, NY: James Currey Publishers/School of American Research Press.

Debord, G. (1996). La société du spectacle. Paris: Gallimard.

Development Workshop. (2005). Terra. Reforma sobre a terra urbana em Angola no período pósguerra: Pesquisa, advocacia e políticas de desenvolvimento. Luanda: Author.

Development Workshop. (2011). Strengthening citizenship through upgrading informal settlements cross-country initiative (Draft Synthesis Report for the World Bank). Luanda: Author.

Ferreira, M. E. (1995). La reconversion économique de la nomenklatura pétrolière. Politique Africaine, 57, 11-26.

Financial Times. (2007). Investors sign up to Angola's miracle. Retrieved from http://www.ft.com/intl/cms/s/0/1e90d442-50ca-11dc-86e2-0000779fd2ac.html\#axzz3NsjjUrMi

Fuller, C., \& Bénéï, V. (2001). The Everyday state and society in modern India. London: Hurst Publishers. 
Gastrow, C. (2013). "Vamos construir!”: Revendications foncières et géographie du pouvoir à Luanda, Angola. Politique Africaine, 132, 49-72.

Gastrow, C. (2014). Negotiated settlements: Housing and the aesthetics of citizenship in Luanda. Angola (Unpublished doctoral dissertation). University of Chicago, Chicago.

Hagmann, T, \& Péclard, D. (2010). Negotiating statehood: Dynamics of power and domination in Africa. Development and Change, 41, 539-562.

Hibou, B. (2011). Anatomie politique de la domination. Paris: La Découverte.

Hodges, T. (2004). Angola: anatomy of an oil state. Oxford. James Currey and Bloomington and Indianapolis: Indiana University Press.

Human Rights Watch. (2007). They pushed down the houses' Forced evictions and insecure land tenure for Luanda's urban poor (Report No. 19-7(A)). Luanda: Author.

Insurance Times. (2012). The Angolan growth miracle. Retrieved from http://www.insurancetimes.net/article/angolan-growth-miracle

Lund, C. (2006). Twilight institutions: Public authority and local politics in Africa. Development and Change, 37, 685-705.

Malaquias, A. (2007). Rebels and robbers: Violence in post-colonial Angola. Uppsala: Nordic Africa Institute.

Messiant, C. (2008). L'Angola postcolonial (pp. 1-2). Paris: Karthala.

Morice, A. (1986). Commerce parallèle et troc à Luanda. Politique Africaine, 17, 105-120.

Navaro-Yashin, Y. (2002). Faces of the State: Secularism and Public Life in Turkey. Princeton: Princeton University Press.

Ondjaki. (2012). Os transparentes. Lisbon: Caminho.

Pearce, J. (2005). An outbreak of peace: Angola's situation of confusion. Cape Town: David Philip Publishers.

Pearce, J. (2016). Political identity and conflict in Central Angola 1975-2002. Cambridge: Cambridge University Press.

Péclard, D. (2008). Les chemins de la "reconversion autoritaire" en Angola. Politique Africaine, 110, $5-20$.

Pepetela. (2012). O Desejo de Kianda. Lisbon: Don Quixote.

Portal do Governo. (2011a). Administração assume gestão do complexo habitacional do Panguila (Governo). 
Retrieved September from http://www.governo.gov.ao/VerNoticia.aspx?id=11534

Portal do Governo. (2011b). Liquidação do Panguila, Icolo e Bengo e Quissama analisada em sessão extraordinária (Governo).

Retrieved from http://www.governo.gov.ao/VerNoticia.aspx?id=12112

Roque, P. C. (2011). Angola: Parallel governments, oil and the neopatrimonial system reproduction (Situation Report). Institute for Security Studies.

Roy, A. (2005). Urban informality: Toward an epistemology of planning. Journal of the American Planning Association, 71,147-158.

Roy, A. (2009a). Why India cannot plan its cities: Informality, insurgence and the idiom of urbanization. Planning Theory, 76-87.

Roy, A. (2009b). Strangely familiar: Planning and the worlds of insurgence and informality. Planning Theory, 8, 7-11.

Schubert, J. (2010). 'Democratisation' and the consolidation of political authority in post-war Angola. Journal of Southern African Studies, 36, 657-672.

Schubert, J. (2017). Working the system. In A political ethnography of the new Angola. Ithaca: Cornell University Press.

Seibert, G. (2007). Auto-organizacao e entreajuda nos bairros peri-urbanos de Maputo e Luanda. In J. Oppenheimer \& I.O.D.S. Raposo (Eds.), Subúrbios de Luanda e Maputo (pp. 163-173). Lisbon: Colibri.

Soares de Oliveira, R. (2007). Business success, Angola-style: Postcolonial politics and the rise and rise of Sonangol. The Journal of Modern African Studies, 45, 595-619.

Soares De Oliveira, R. (2015). Magnificent and beggar land: Angola since the civil war. London: Hurst Publishers.

Sogge, D. (2009). Angola 'Failed' yet 'Successful' (Working Paper No. 81). Madrid: Fride.

Tomas, A. A. (2012). Refracted governmentality: Space, politics and social structure in contemporary Luanda (Unpublished doctoral dissertation). Columbia University, New York.

Trouillot, M.-R. (2001). The anthropology of the state in the age of globalization. Close Encounters of the Deceptive Kind. Current Anthropology, 42(1), 125-138.

Udelsmann Rodrigues, C. (2009). Angolan cities: Urban (re)segregation? In F. Locatelli \& P. Nugent (Eds.), African cities: competing claims on urban spaces (pp. 37-53). Leiden: Brill. 
Intimate Encounters with the State in Post-War Luanda, Angola Chloé Buire

Utas, M. (Ed.). (2012). African conflicts and informal power. Big men and networks. London: Zed Books. 